\title{
The temporal evolution of chemical and physical properties of magmatic systems
}

\author{
LUCA CARICCHI ${ }^{1 *} \&$ JON BLUNDY ${ }^{2,3}$ \\ ${ }^{1}$ Section of Earth and Environmental Sciences, Rue des Maraîchers 13, \\ 1205, Geneva, Switzerland \\ ${ }^{2}$ School of Earth Sciences, University of Bristol, Wills Memorial Building, Bristol BS8 1RJ, UK \\ ${ }^{3}$ Division of Geological and Planetary Sciences, California Institute \\ of Technology, 1200 E. California Blvd, Pasadena, CA 91125, USA \\ *Corresponding author (e-mail: luca.caricchi@unige.ch)
}

\begin{abstract}
Exactly 100 years ago the great Canadian-born petrologist N. L. Bowen published two seminal works on the chemical differentiation of magmas in which he posed the basis for a physicochemical understanding of the fractionation of crystals from melts in molten rock. A subsequent century of research and technological advances has enhanced our understanding of the physics and chemistry of magmatic systems and their temporal evolution. The image of sub-volcanic magmatic systems has evolved greatly in that time, from a simple 'boiling vat' concept of molten rock in which bubbles, crystals and melt separate gravitationally to a recognition that magma vats are relatively rare and that most magmatic systems spend much of their lifetime in a partially molten, or mushy, state. Real magmatic systems appear to be organized into a series of storage regions periodically connected by feeding structures transferring magma (and heat) at different fluxes. Magma fluxes between the different portions of this plumbing system, and the variation of the chemical and physical properties of magma as it rises through the crust, exert essential controls on the eruptive modalities of volcanoes and the geochemistry of their products. This book presents a collection of contributions that use petrology, geochemistry, geochronology and numerical modelling to identify the processes operating at different depths within magmatic systems and to characterize the fluxes of magma between them.
\end{abstract}

The foundations of modern igneous petrology were laid approximately 100 years ago by Norman Levi Bowen who, working at the Geophysical Laboratory of the Carnegie Institution of Washington (USA), used a combination of high-temperature experiments and field observations to assert that chemical differentiation was controlled primarily by the settling out of crystals from molten rock in magma chambers (e.g. Bowen 1915a, b; Fig. 1). In Bowen's own words (1915b): 'The decision is reached that [igneous] differentiation is controlled entirely by crystallization. The sinking of crystals and the squeezing out of residual liquid are considered the all-important instruments of differentiation'. This was a significant step forward in our understanding of the chemical evolution of magmatic systems and much of the subsequent work on igneous differentiation has been predicated on the existence of magma chambers as vats of crystalpoor magma in the crust wherein heat loss to the surroundings causes crystallization that drives differentiation. However, several lines of evidence suggest that the magma chamber paradigm is not appropriate for many crustal magmatic systems and needs to be re-evaluated. First, thermal models of crustal magmatism reveal the difficulty in generating and then sustaining large bodies of true magma ( $>40 \%$ melt) in the shallow crust (Glazner et al. 2004; Annen et al. 2008; Annen 2009; Schöpa \& Annen 2013). Volcanic eruptions of relatively crystal-poor magma testify to the existence of such bodies, but thermal models together with geochronological and geochemical data require that this is a relatively transitory physical state (Wilson \& Charlier 2009; Cooper \& Kent 2014; Wotzlaw et al. 2014). Second, petrological studies of igneous rocks reveal a level of geochemical and textural complexity that cannot be reconciled with simple precipitation from a melt, instead suggesting physical and chemical interaction of crystal residues with melts over long periods of time in a thermally fluctuating mush environment (Paterson et al. 2011; Humphreys et al. 2012; Thomson \& Maclennan 2012; Cashman \& Blundy 2013). Intrusive bodies from small laccoliths to giant batholiths appear to have formed not in one large belch of magma, but via the amalgamation of many smaller, interacting pulses over time periods of more than 100000 
years (Coleman et al. 2004; Michel et al. 2008; Schoene et al. 2012). Even volcanic rocks produced during some of the largest known eruptions (e.g. Taupo, New Zealand or Bishop Tuff, USA) testify to several disparate melt-rich lenses or pockets that only coalesced shortly before or during eruption (Hildreth \& Wilson 2007; Cashman \& Giordano 2014; Ellis et al. 2014; Wotzlaw et al. 2014), rather than one giant pre-eruptive magma chamber. Lastly, geophysical techniques, such as seismology, gravity and magnetotellurics, have been signally unsuccessful in identifying large melt-dominated regions in the shallow crust beneath most arc volcanoes (Hill et al. 2009; Paulatto et al. 2012). Where large, crustal geophysical anomalies do exist, such as the Altiplano-Puna Magma Body beneath Bolivia (Ward et al. 2014; Comeau et al. 2015), these are better reconciled as large bodies of partially molten rock rather than giant liquid-rich chambers. Thus, the standard, background state for most magmatic system appears to that of a partially molten mush with $\ll 40$ vol\% melt that grows incrementally over time through repeated additions of new magma (Marsh 1981, 1989; Bachmann \& Bergantz 2006; Hildreth \& Wilson 2007; Fig. 2).

Although it is straightforward to envisage crustal magmatic systems as multiple reservoirs of mush distributed at different depths, it is important to identify the main factors controlling the temporal evolution of the chemistry and physical properties of magmatic systems to understand their behaviour over time. This, in turn, impacts on our ability to anticipate volcanic hazards, interpret geophysical signals at restless volcanoes or model crustal differentiation. The contributions in this book focus on magmatic systems with different physical and chemical characteristics and use different approaches to their study, so providing a wide perspective on the variety of modern methods that can be applied to understanding the chemical, physical and temporal evolution of magmatic systems. This book demonstrates how the capability, effort and intuition of N. L. Bowen a century ago triggered a stimulating research field that can today be investigated with a bewildering variety of approaches that transcend traditional disciplinary boundaries within the earth sciences. In this introduction we will draw upon some fundamental, yet familiar, thermodynamic aspects of magmatic systems to provide a context to the contributions to this book.

\section{Magma fluxes and phase equilibria}

Heat loss leads to magma crystallization and, because crystals and melt chemistry are physically and chemically different, the chemical composition of the residual melt changes during cooling (Bowen
$1915 a, b)$. It follows that the timespan over which a residual melt of a given composition exists in a magmatic reservoir is inversely proportional to the rate of cooling (Marsh 1981). In other words, the longer the time a given melt is present in the system, the higher is the probability that melt of that composition will be extracted from the system (Fig. 2). When Bruce Marsh published this idea at the beginning of the 1980s, the accumulation of magma in the crust was considered to occur on much shorter timescales than the duration of cooling. Within this assumption the residual melt composition that would have been present for the longest time in a magmatic reservoir would correspond to the temperature at which the release of latent heat of crystallization was at a maximum (Marsh 1981). In effect, chemical differentiation then became a question of how heat is lost from a single body of initially crystal-poor magma. In the last 20 years, petrology, thermal modelling, structural geology and geophysical monitoring of restless volcanoes have demonstrated that magmatic systems are constructed by the periodic injection of magma over prolonged periods of time (de Saint-Blanquat et al. 2001; Coleman et al. 2004; Glazner et al. 2004; Annen 2009; Biggs et al. 2011; Caricchi et al. 2012; Humphreys et al. 2012). Piecemeal emplacement complicates the temporal pattern of heat loss and, consequently, the inferences that can be drawn about the chemical evolution of the system and the probability of extracting melt of one composition versus another. For example, Melekhova et al. (2013) showed that a combination of the variation of crystal content as a function of temperature in the injected magma and the rate at which that magma is supplied to the reservoir controls the relative volumes of residual melts of different compositions present at different times.

The effect of phase equilibria on the distribution of residual melt composition can be illustrated by considering the evolution of residual melt fraction $(F)$ and silica content of an $\mathrm{H}_{2} \mathrm{O}$-bearing basalt undergoing fractional crystallization (Nandedkar et al. 2014; Fig. 3). Rapid decrease of $F$ as a function of temperature $(T)$ occurs when the crystallizing assemblage has a chemical composition similar to the melt. In this temperature interval the silica content of the residual melt changes little (low $2 \mathrm{SiO}_{2} /$ $\partial T$; interval I in Fig. 3). Conversely, the onset of crystallization of hornblende, which has a much lower $\mathrm{SiO}_{2}$ content than the melt from which it precipitates, leads to small $\partial F / \partial T$ and high $\partial \mathrm{SiO}_{2} / \partial \mathrm{T}$ (interval II in Fig. 3). At still lower temperatures, when the residual melt approaches the granitic minimum compositions, $\partial F / \partial T$ increases and $\partial \mathrm{SiO}_{2} / \partial T$ decreases. Eutectic crystallization is an extreme version of this process with $\partial F / \partial T=\infty$ and $\partial \mathrm{SiO}_{2} / \partial T=0$. 


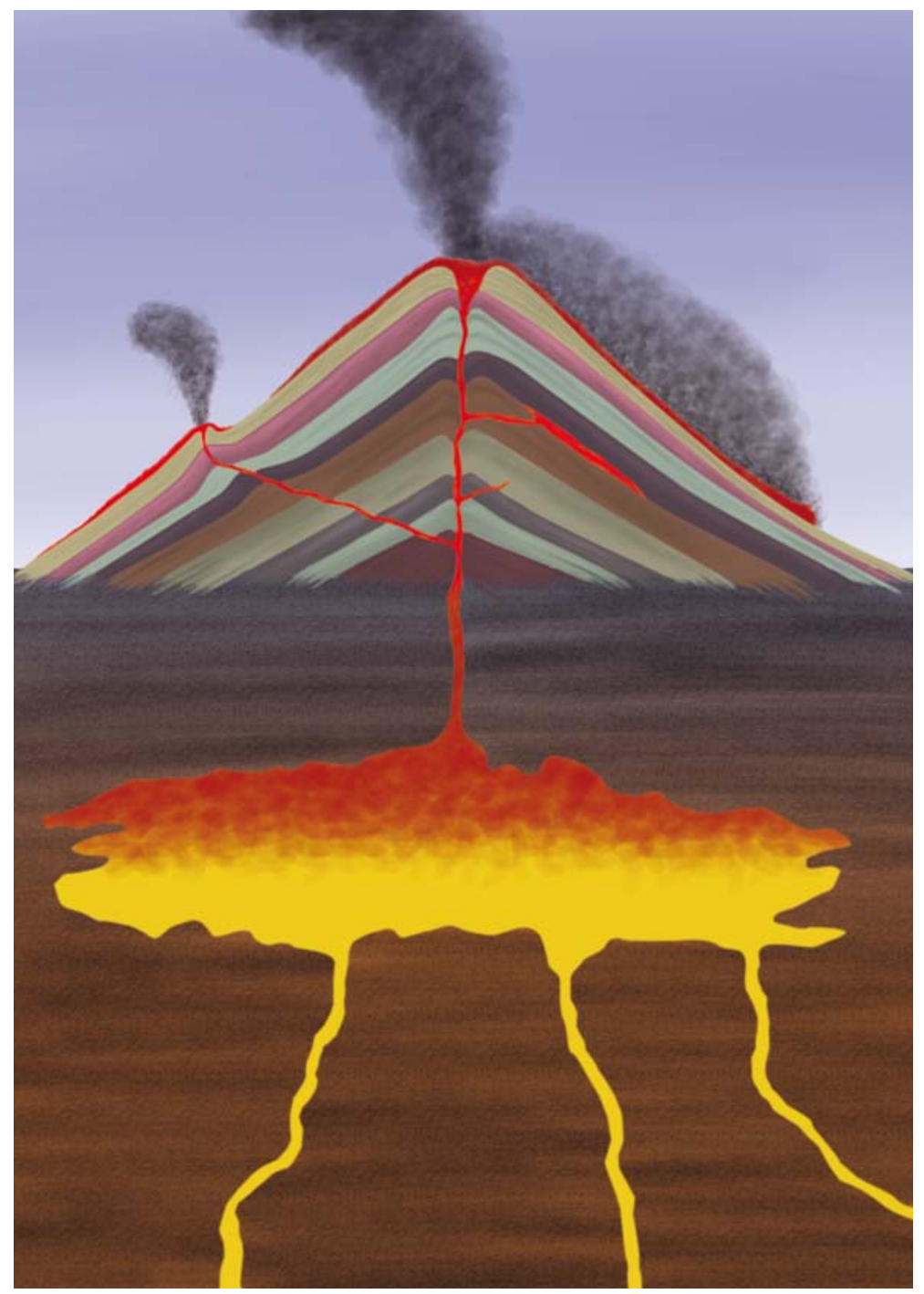

Fig. 1. Illustration of a model magma chamber as imagined on the basis of the pioneering work of N. L. Bowen and others.

Even for the case of continuous injection of magma, the average temperature within the volume of emplaced magma decreases (Marsh 1981; Caricchi et al. 2014). A simple thought experiment helps to understand this somewhat counterintuitive statement. At the moment a parcel of magma is injected into the crust, the total volume of the magmatic system corresponds to the volume of injected magma. At this instant, the temperature averaged over the entire magmatic system volume is equal to the injection temperature. With continuous magma injection, even if the total amount of heat added to the system increases, there will always be magma that cooled below the injection temperature and, therefore, the temperature averaged over the total volume of the magmatic system will be lower than the initial magma injection temperature. In turn, the cooling rate of an intrusion for a fixed magma injection rate is controlled by the temperature difference between magma and host rock and the rate of latent heat release. Where crystallization is driven by volatile exsolution during decompression and ascent, as is the case for many hydrous silicic magmas, the release of latent heat may even lead to a rise in magma temperature (Blundy et al. 2006). 


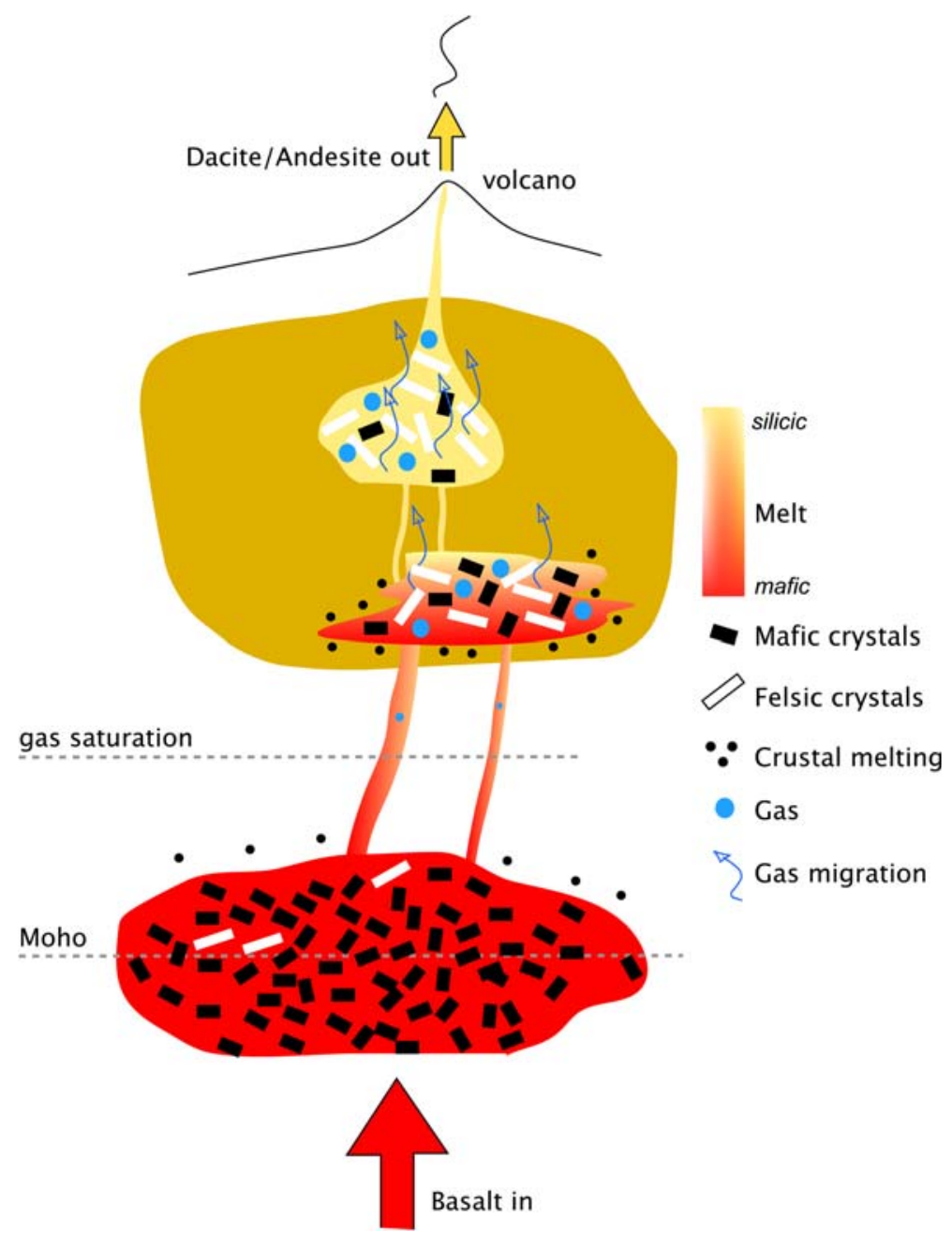

Fig. 2. Schematic illustration of a crustal magmatic system composed of various storage regions connected by sub-vertical feeding structures. Magma injected from the mantle fractionates at depth and residual melts are eventually extracted to feed middle to upper crustal reservoirs. With decreasing depth within the system the residual melt becomes progressively more evolved chemically. Crustal melting at different depths may also contribute to the chemical evolution. The extent to which the magmatic system is vertically continuous or discontinuous (as shown) remains unknown. A key feature is that melts, crystals and gases can move independently of each other through the system.

Considering the phase diagram in Figure 3, the largest rate of latent heat release and the minimum in $\mathrm{dSiO}_{2} / \mathrm{d} T$ are achieved in temperature intervals I and III and, therefore, the residual melt compositions present within these temperature ranges should be those most likely to be found in magmatic systems. This would suggest that some intermediate, andesitic magmas commonly erupted in arcs may be the result of mingling/mixing of mafic residual melt produced in the lower crust and felsic melts occupying the shallower portions of magmatic systems, rather than true intermediate liquids (Reubi
\& Blundy 2009). In a contribution to this book, Bouvet de Maisonneuve et al. (2015) report petrographic, geochemical and temporal constraints on the interaction between basaltic and dacitic magmas that preceded the andesitic Plinian eruption of Tavurvur volcano (Papua New Guinea) in 2006.

True andesitic melts can be produced simply by crystallization provided that the melt fluxes from the mantle are sufficient to generate the appropriate melt fractions. To show this we performed thermal modelling to simulate the injection of basaltic magma into the lower crust using the experimental 


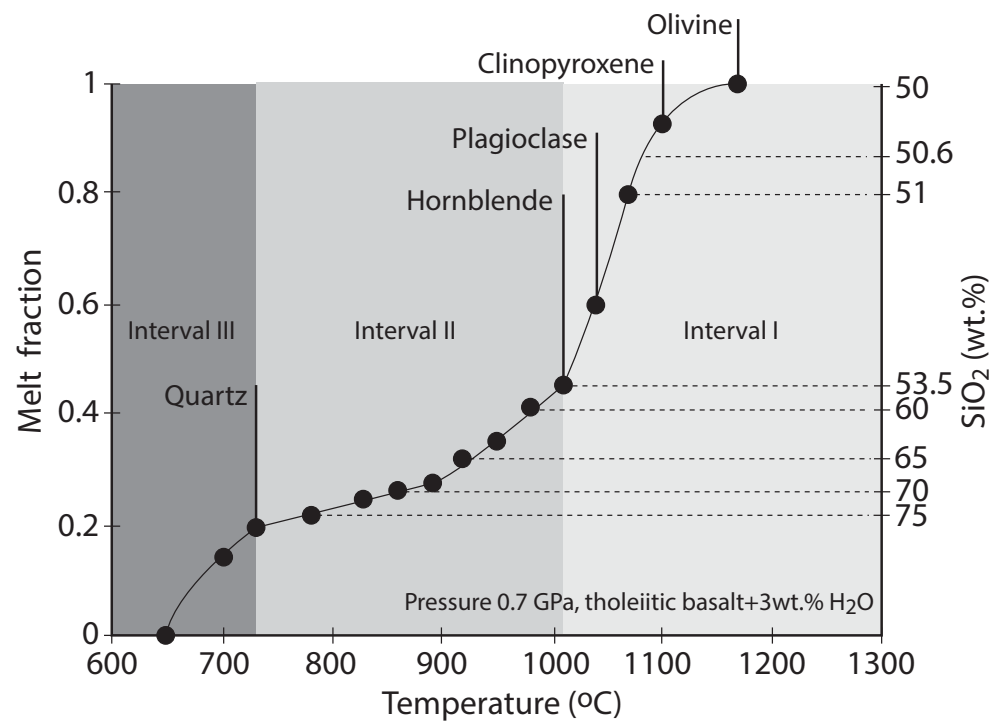

Fig. 3. Variations of melt fraction and $\mathrm{SiO}_{2}$ content of the residual melt as function of temperature for an $\mathrm{H}_{2} \mathrm{O}$-bearing tholeiitic basalt during fractional crystallization. Modified from Nandedkar et al. (2014).

phase relations of Nandedkar et al. (2014). The description of the model, for the analogous case of upper crustal intrusion, is reported in Caricchi et al. (2014); in the present simulations the initial temperature of the rock surrounding the intrusion was increased to $900^{\circ} \mathrm{C}$ to better match the lower crust. The diameter of the system was kept fixed at $24 \mathrm{~km}$ for all simulations; each new magma pulse was injected into the core of the intrusion; and the final injected volume was always $1000 \mathrm{~km}^{3}$.

The model results (Fig. 4) show that the most abundant residual melt compositions present in the lower crust become more felsic with decreasing flux of basaltic magma from the mantle and that a compositional gap appears between 53.5 and about $60 \mathrm{wt} \% \mathrm{SiO}_{2}$. The lower $\mathrm{SiO}_{2}$ end of this compositional gap corresponds to the silica content of the residual melt at the onset of hornblende crystallization (Fig. 3; Nandedkar et al. 2014). These simulations demonstrate how magma fluxes can play an important role in controlling the chemical composition of residual melt present within magmatic systems. The thermal modelling results also indicate that residual melt with $\mathrm{SiO}_{2}$ contents between 53.5 and $60 \mathrm{wt} \%$ are relatively rare because amphibole crystallization changes significantly the $\mathrm{SiO}_{2}$ content of the residual melt over a restricted $T$ range (Fig. 3). Consistent with the rarity of andesitic melts generated by this mechanism in the lower crust, many andesite magmas show petrographic evidence of mingling/mixing; in these cases a simpler explanation for their genesis would be interaction between mafic and felsic magmas (Nakamura
1995; Murphy et al. 1998; Nakagawa et al. 1999; Frey \& Lange 2010; Humphreys et al. 2012; Jeffery et al. 2013; Kilgour et al. 2013).

Magma flux is demonstrably a fundamental parameter in determining igneous differentiation. One contribution in this book approaches the determination of intrusive magma fluxes at different depths within the crust using the structure of the metamorphic aureole surrounding intrusions (Floess \& Baumgartner 2015). This paper shows that the relative distance and thickness of metamorphic isograds depend not only on the total volume of magma injected, but also on the frequency at which single magma batches are injected. In another contribution, Muir et al. (2015) combine radiometric dating with remote sensing to constrain extrusive magma fluxes from Uturuncu Volcano in the Bolivian Altiplano. Their data show that the periodicity of the eruptions and the volume released in each extrusive event are not constant. The temporal evolution of temperature within a magmatic system is also controlled by the depth of the different storage regions (Annen et al. 2006; Solano et al. 2012). Zanon (2015) use fluid inclusion microthermometry and geochemistry to determine the structure of the magmatic plumbing system in a volcanic sector of the Azores Archipelago.

\section{Phase equilibria, physical properties of magma and melt extraction}

The evolution of residual melt chemistry and crystallinity during cooling has a profound effect on 


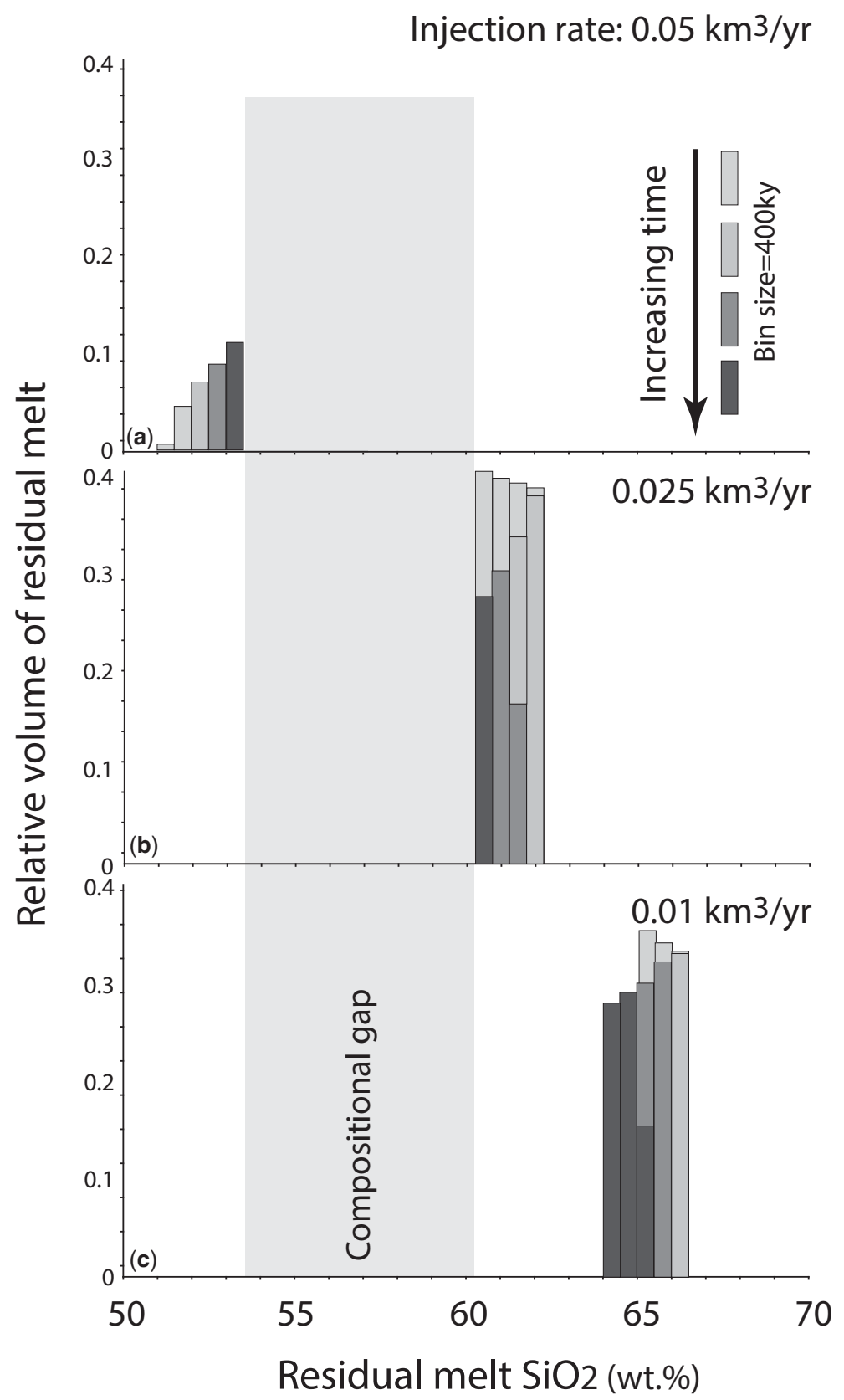

Fig. 4. Histograms showing the distribution in time of the relative volume of residual melt present in magmatic reservoirs assembled at the base of the crust $(30 \mathrm{~km})$ by the continuous injection of basalt from the mantle. The calculations were made using the approach to thermal modelling presented in Caricchi et al. (2014) combined with the basaltic phase equilibria of Nandedkar et al. (2014). The histograms are shaded for time from the beginning of magma intrusion and show the relative volumes of residual melt of different compositions present within the magmatic reservoir. From top to bottom the rate of basalt injection into the system decreases and a compositional gap appears in the silica range corresponding to temperature interval II in Figure 3. 
the physical properties of magma and residual melt (e.g. density and viscosity; Caricchi et al. 2007; Giordano et al. 2008; Mueller et al. 2011). The interplay between the thermal evolution of a magmatic system and changes in magma chemistry and physical properties controls the temperature window in which residual melt can be extracted from crystallizing magmas (Dufek \& Bachmann 2010). Extracted residual melt is mobile and thus can be transported to different levels within the magmatic plumbing system or potentially erupted at the surface. Moreover, the evolution of the physical properties of magmas interacting at different levels within a magmatic system as they evolve towards thermal equilibrium has an important effect on the geophysical signals produced by the periodic replenishment of magma storage regions (Longo et al. 2011). In the previous section we explored the combined action of magma fluxes and phase equilibria in controlling the chemistry and relative volume of different residual melts. In this section we use simple, schematic binary systems to illustrate the relationships between phase equilibria, the physical properties of magmas and the chemistry of residual melts that are most likely to be extracted and transported within the magmatic system.

It has long been recognized that over the crystallization interval between liquidus and solidus the proportions of melt and solid do not change linearly with temperature: this is abundantly clear from simple binary eutectic systems (Fig. 5a). In a binary $(A-B)$, with a eutectic point $(e)$, crystallization for any composition terminates at the eutectic temperature. The relative proportions of residual melt and crystals as a function of temperature are very sensitive to the initial magma composition (Fig. $5 b)$. The observed difference in the evolution of crystallinity as a function of temperature for magmas of slightly different compositions becomes exaggerated in more complex, natural systems more (a)

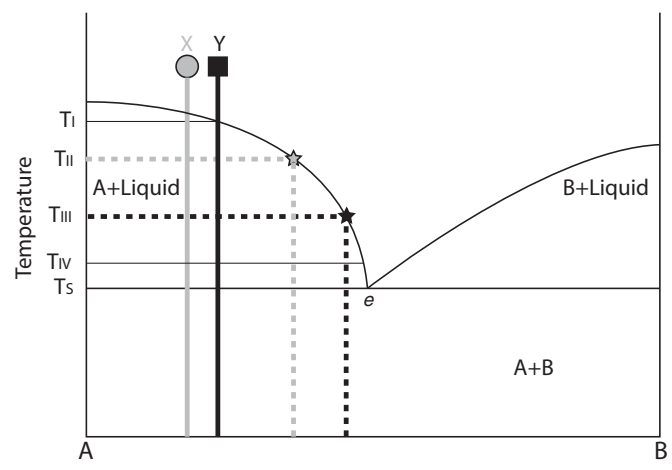

(b)

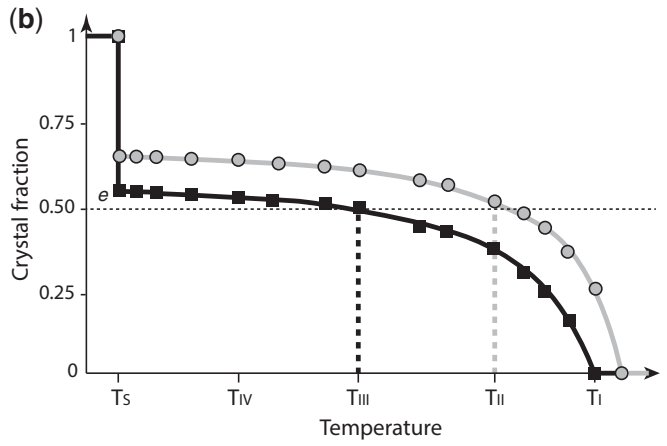

(c)
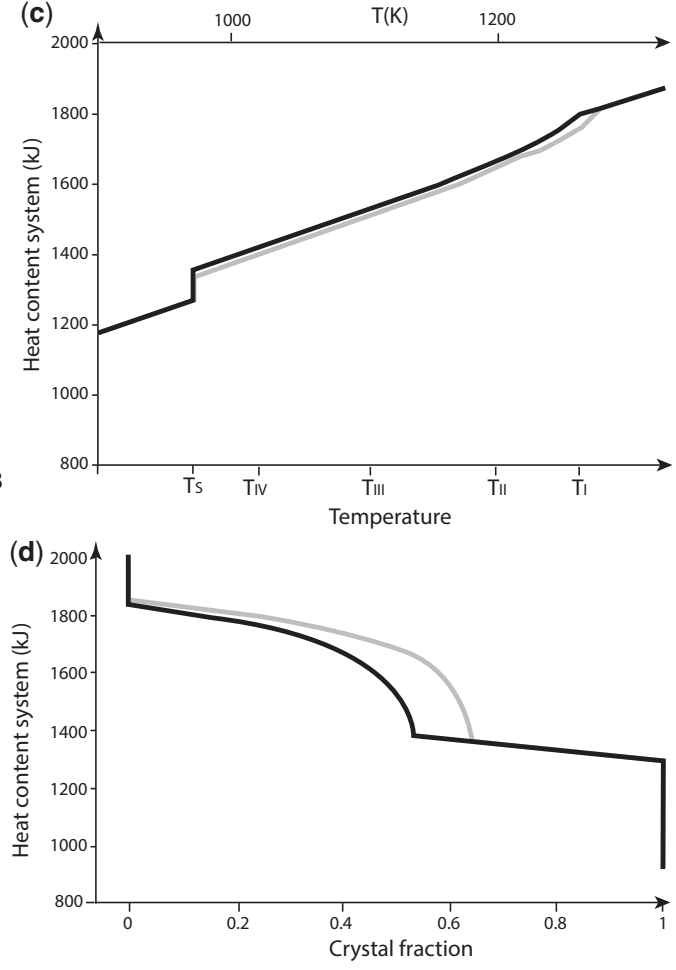

Fig. 5. (a) Schematic binary phase diagram used to calculate the evolution of crystal fraction as a function of temperature as presented in (b), for two compositions $X$ (in grey) and $Y$ (in black). The horizontal dashed lines in (a) show the temperature at which the fraction of crystals in the magma reaches a value of 0.5 , while the vertical lines indicate the corresponding residual melt composition. Dashed lines in (b) show the temperature at which the crystal fraction is 0.5 . Note that the evolution of crystal fraction with temperature is sensitive to the starting composition.

(c) Heat content of the system as a function of temperature for $X$ (grey) and $Y$ (black), calculated as described in the text.

(d) Heat content of the system as a function of crystal fraction for $X$ (grey) and $Y$ (black). Calculations were performed for $1 \mathrm{~kg}$ of rock. 
similar to natural magmas in which eutectic, peritectic and cotectic reactions occur. This is shown in Figure 6 by means of a binary $(A-C)$, with an intermediate, incongruent phase $(B)$. Such systems contain both a eutectic $(e)$ and a peritectic $(p)$. There are abundant examples of such systems in nature (e.g. $\mathrm{Mg}_{2} \mathrm{SiO}_{4}-\mathrm{SiO}_{2}$ ); for illustrative purposes we adopt a schematic phase diagram with standard topology. For all compositions lying between $A$ and $B$ in Figure 6, crystallization terminates at the eutectic, whereas between $B$ and $C$ the last residual melt is exhausted at $p$. For compositions between $A$ and $p$ crystallization terminates at the eutectic. Between $p$ and $B$ crystallization also ends at the eutectic point; however, the peritectic reaction of $C$ and residual melt of composition $p$ leads to the crystallization of $B$ and an important decrease in residual melt fraction (Fig. 6a, b).

The most efficient mechanisms responsible for extraction of felsic residual melts from crystallizing magma operate at crystallinities higher than $c$. 50 vol\% (Bachmann \& Bergantz 2004; Dufek \& Bachmann 2010). In the example shown in Figure 5, we consider two different initial melt compositions $(X$ and $Y$ ) and track the variation of crystallinity as a

(a)
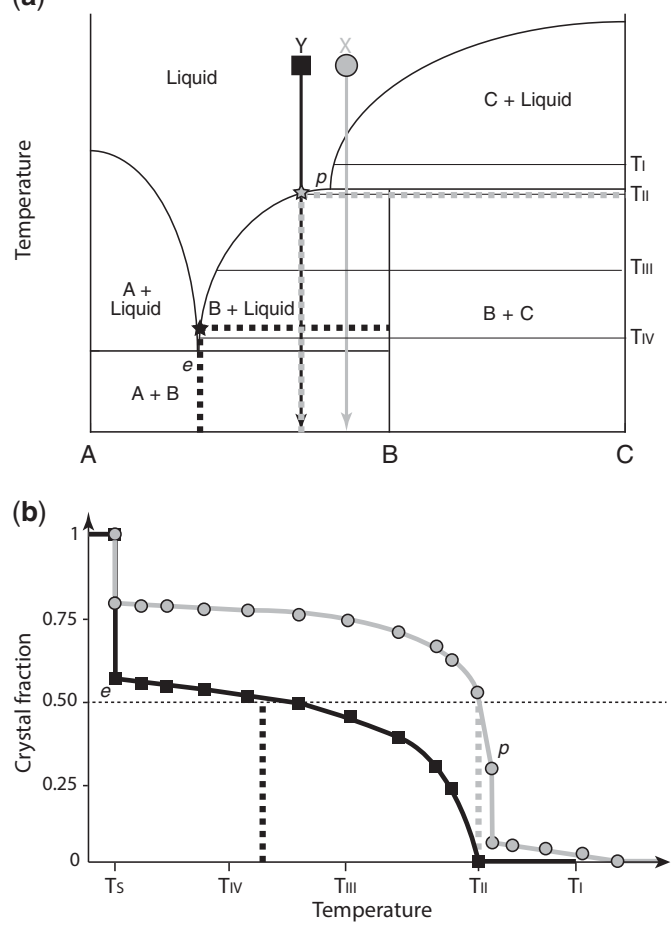

function of temperature (Fig. 5b). The temperature at which the two magmas reach a crystal fraction of 0.5 is significantly different even if the initial composition and liquidus temperature are similar (Fig. 5b). As a consequence the residual melt composition that is most likely to be extracted from two magmas with similar initial compositions is potentially very different. Additionally, because the temperatures at which crystal fractions reach 0.5 for $X$ and $Y$ are different, the physical properties (e.g. viscosity) of the extracted melts also differ. Following the same argument, the composition and physical properties of the extracted residual melts will be even more distinct for the two examples shown in Figure 6. In more complex natural systems, the evolution of melt fraction $(F)$ with temperature $(T)$ is less tractable. The behaviour of such systems is poorly understood because a relatively small number of experimental studies have embraced the full crystallization interval for a given starting composition (Piwinskii \& Wyllie 1968; Piwinskii 1975; Whitney \& Stormer 1985; Melekhova et al. 2013; Nandedkar et al. 2014). This, in part, reflects the difficulty of performing experiments close to the solidus, where quenching effects tend to obliterate the prior presence of melt and is, in part, due to an
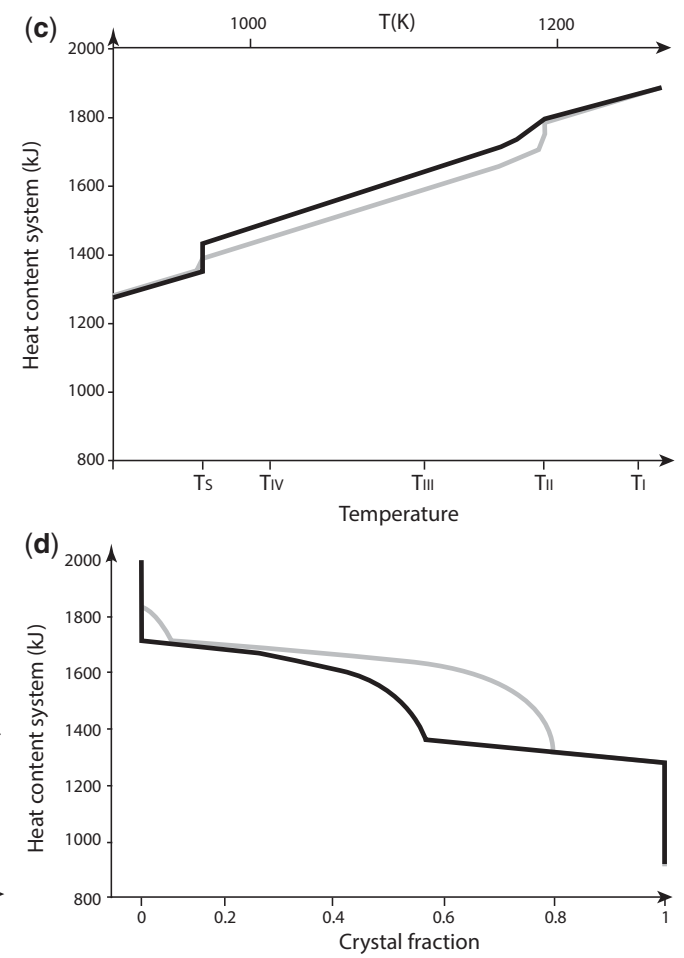

Fig. 6. Same as Figure 5 but for a different schematic binary diagram (a) containing both a eutectic and a peritectic point p. Calculations were performed for $1 \mathrm{~kg}$ of rock. 
understandable focus on the liquid lines of descent that drive differentiation. As a consequence, almost all dynamic models of magmatic behaviour employ either linear $T-F$ relationships or overly simplified ones. The complexity that arises from analysis of simple binary systems suggests that modelling of magmatic system should be based upon appropriate phase diagrams. The thermodynamic software MELTS (Ghiorso \& Sack 1995; Asimow \& Ghiorso 1998) and its later derivatives offer an excellent platform with which to approach the complexity of the relationship between melt fraction and temperature for complex, natural systems. Improved calibration of MELTS for hydrous phases, such as amphibole and mica, will greatly enhance its use in modelling evolved, hydrous crustal magmas.

The crystallization (and melting) phenomena described above become even more interesting when heat (enthalpy) rather than temperature is cast as the progress variable. Experimental petrologists, such as Bowen, set the temperature of their experiments and adjust the heat content of the experimental charge to maintain constant temperature by varying the power input to the furnace. In nature temperature varies as heat moves into and out of the system. A number of studies have looked at enthalpy (or entropy) as a process variable in basaltic, mid-ocean ridge magmatic systems (Asimow et al. 1997; Stolper \& Asimow 2007; Katz 2008), but such approaches are rare in continental magmatic systems.

For illustrative purposes we calculated the heat content for the four systems described in Figures 5 and 6 as functions of temperature and crystallinity by assigning a fixed specific heat to the solid phase $\left(C p_{\mathrm{s}}\right)$ and to the residual melt $\left(C p_{\mathrm{m}}\right)$ and computing the enthalpy $(H)$ as:

$$
H=X_{\mathrm{s}} C p_{\mathrm{s}} T+X_{\mathrm{m}} C p_{\mathrm{m}} T+L X_{\mathrm{m}}
$$

where $X_{\mathrm{s}}$ is the fraction of solid, $X_{\mathrm{m}}$ is the residual melt fraction, $T$ is temperature and $L$ is the heat of fusion. For $C p_{\mathrm{s}}, C p_{\mathrm{m}}$ and $L$ we adopted the values presented by Caricchi \& Blundy (2015). The highest liquidus temperature (i.e. for composition $X$ in both Figs $5 \& 6$ ) was taken to be $1000^{\circ} \mathrm{C}$ and the solidus (i.e. eutectic) temperature was set at $700^{\circ} \mathrm{C}$ for all calculations. The results highlight the nonlinear variation of the heat content of magmas as a function of both temperature (Figs 5c \& 6c) and of crystallinity (Figs 5d \& 6d). Particularly interesting are the figures showing the variation of enthalpy as a function of crystal fraction (Figs $5 d \& 6 d$ ). In Figure 5d, three regions are evident where significant variations of enthalpy occur across a restricted range of crystallinity. These regions correspond to near-liquidus and near-solidus temperatures and to an intermediate temperature range over which crystallinity changes little (Fig. 5b).

The slope of the enthalpy versus crystallinity curve provides information on how a magmatic system responds to additions or subtractions of heat. When the slope is low (flat), small changes in enthalpy result in large changes in crystallinity. Conversely, when the slope is high (steep) large changes in enthalpy lead to negligible changes in crystallinity. This situation arises near the liquidus and the solidus of the system and, for compositions $X$ and $Y$, at crystallinities of 0.65 and 0.55 , respectively. We will use the term 'critical' to describe the three regions where the enthalpy changes steeply with crystal fraction. Magmas of compositions $Y$ and $X$ that are emplaced at their liquidus temperatures and lose heat to their surroundings will tend to migrate down-temperature to these three critical crystallinities; conversely rocks of composition $Y$ and $X$, once heated to super-solidus temperature, will tend to migrate up-temperature towards the corresponding critical melt fractions. Outside the critical values, $X$ and $Y$ have crystal (or melt) fractions that are extremely sensitive to small enthalpic perturbations. In other words, small changes in added or subtracted heat lead to large changes in crystallinity above or below the critical values. Because magma rheology is very sensitive to crystallinity, magmas outside the critical regions can be readily remobilized if heat is added to the system. Very similar behaviour can be deduced for compositions $X$ and $Y$ in the peritectic system (Fig. 6), although the intermediate critical crystallinity is displaced to 0.80 and 0.58 , respectively. It is important to emphasize that critical crystallinity is a function of bulk composition and phase diagram topology and we cannot simply generalize from one system to another.

These simple calculations have a direct impact on the probability of magma of a given crystallinity and residual melt composition being present in reservoirs periodically refilled by magma injections and the likelihood of that magma having a sufficiently low viscosity to be erupted. For example, considering initial composition $Y$ in Figures 5 and 6 , the magma present for the longest times within a reservoir will have crystallinities that lie close to critical values, i.e. near-liquidus, crystal fraction of 0.55 (0.58 in Fig. 6d), or solidus (Figs $5 d \&$ $6 d)$. Indeed, it is in these regions where increasing crystallinity towards lower temperatures is limited by the release of latent heat in proximity to a region of critical crystallinity, whereas addition of heat results in the rapid resorption of crystals until the next critical crystallinity is achieved. Because, even with periodic magma injection, the average temperature in a reservoir tends to decrease, the largest portion of magma in a reservoir will 
progressively evolve towards lower temperatures, increasing the probability of finding magmas at near-solidus temperatures (Figs 5d \& 6d).

Two contributions in this book explore various aspects of the chemical and physical evolution of periodically replenished magmatic reservoirs. Caricchi \& Blundy (2015) performed experiments to obtain a phase diagrams for dacite magmas of the variety that commonly feed large eruptions. In line with the simple arguments developed above, they show that natural magmas tend to evolve to a physical and thermal state at which the variation of crystallinity and residual melt chemistry as a function of enthalpy is minimized. Montagna et al. (2015) use numerical simulations to explore the consequences of contrasting physical properties of resident and injected magma, together with different reservoir geometry, for subvolcanic reservoir dynamics.

\section{Architecture of subvolcanic reservoirs}

Geophysical and geochemical evidence suggests that subvolcanic reservoirs are, in many cases, composed of multiple pockets of eruptible magma that may have been separated for most of their lifetime (Miller \& Smith 1999; Bachmann \& Bergantz 2008; Cashman \& Giordano 2014; Cooper \& Kent 2014; Ellis et al. 2014; Wotzlaw et al. 2014). The accumulation of residual melt in these separate reservoirs has been modelled hitherto solely as a single, large accumulation in the upper portion of a single reservoir. However, the recent data call for a revision of our conceptual understanding of the thermal and chemical structure of magma storage regions in the crust. Understanding magmatic interactions within and between different storage regions will inform models for eruption triggering, which are currently based on reservoirs with relatively simple geometry. Recently, Wotzlaw et al. (2014) showed the possible influence of the arrangement of eruptible pockets of magma within larger volumes of highly crystallized magma on the mechanisms potentially leading to large eruptions. The connection of eruptible and buoyant magma pockets distributed at different depths within a magmatic reservoir can lead to a significant increase in buoyancy overpressure and eventually bring the magmatic system into a critical state (Wotzlaw et al. 2014). Movement of melts relative to their crystalline framework by mechanisms such as compaction (e.g. McKenzie 1984; Rabinowicz \& Vigneresse 2004; Solano et al. 2012; Connolly \& Podladchikov 2015) or deformation (Stevenson 1989; Holtzman et al. 2003) can further complicate the picture in terms of both the physical distribution of melt-rich pockets and the chemical evolution of melts via reactive flow through the matrix (Solano et al. 2014). Chemical models that are predicated upon crystal-melt fractionation in a melt-dominated magmatic system are unable to capture the complexities of reactive melt transport, as has been demonstrated for mantle melting regimes (e.g. Navon \& Stolper 1987; Reiners 1998).

By reviewing existing data on U-series crystal ages Cooper (2015) shows that accessory minerals, such as zircon, record protracted pre-eruptive residence times while approximately half of the major phases collected in eruptive products are less than $10 \mathrm{kyr}$ older than the eruption. These data have been interpreted to result from the long-term storage of zircons in highly crystallized or solidified magma bodies, which are rapidly remobilized before eruption (Wilson \& Charlier 2009; Charlier \& Wilson 2010; Storm et al. 2011). Interestingly, zircons from the same rock sample crystallized over different periods of time, which suggests that zircons from different portions of the subvolcanic reservoir are assembled before eruption (Davidson et al. 2007; Storm et al. 2014). This implies that zircons provide information on the thermal and chemical conditions of a volumetrically larger portion of the magmatic reservoir than that erupted. Zellmer et al. (2015) show that erupted magmas contain a significant fraction of crystals that are recycled from different portions of magmatic reservoirs. Together these studies paint a complex picture of magmatic reservoirs, which is quite different from the idealized model of Figure 1.

The increasing amount of experimental data available for magmas of different compositions and the increasing reliability of thermodynamic models (e.g. MELTS and its derivatives - Gualda et al. 2012; Gualda \& Ghiorso 2014), in combination with the greater spatial resolution at which chemical analysis of minerals can be performed, provide ample opportunity to study the complexity and evolution of physical conditions in subvolcanic reservoirs using mineral chemistry (e.g. Cashman $\&$ Blundy 2013). Furthermore, the increasing precision of geochronological methods is already enhancing our ability to constrain timescales of magmatic processes and the dynamics of eruptible magma extraction, assembly and eruption (Storm et al. 2011; Schoene et al. 2012; Wotzlaw et al. 2013; Barboni \& Schoene 2014; Caricchi et al. 2014; Cooper \& Kent 2014; Wotzlaw et al. 2014).

\section{Volcanic conduits}

Movement of melts between interconnected crustal reservoirs gives rise to the different magma fluxes described above. How melts move depends critically on their physical and chemical characteristics. 
The final rise of magma to the surface is accompanied by a decrease in volatile solubility (Newman \& Lowenstern 2002). This leads to the formation of gas bubbles (Gonnermann \& Manga 2007) and crystallization once magma becomes watersaturated (Blundy \& Cashman 2001), thereby causing significant changes in the chemistry and physical properties of the ascending magma (Gonnermann \& Manga 2007). While the drop in volatile solubility decreases magma density, the release of $\mathrm{H}_{2} \mathrm{O}$ increases magma viscosity both because of its effect on residual melt viscosity and through degassing-driven crystallization (Caricchi et al. 2007; Giordano et al. 2008). The relative magnitude of these decompression-induced modifications to the properties of magmas can either enhance or inhibit their ascent to the surface. Ultimately, the balance between the different processes and the rate of gas loss during ascent plays a fundamental role in controlling eruption dynamics. Reubi $\boldsymbol{e t}$ al. (2015) determine the rate of magma degassing during ascent using ${ }^{210} \mathrm{~Pb}-{ }^{226} \mathrm{Ra}$ disequilibria in magmas erupted between 1998 and 2010 at Colima Volcano (Mexico). Their study reveals that volcanic activity at Colima is sustained by the repeated intrusion at shallow depth of relatively small volumes of magma, which suggests that the shallow feeding system is composed of a plexus of dykes. Finally, Pla \& Álvarez-Valero (2015) explore the conditions of magma ascent in dykes by allying data from crustal xenoliths with numerical modelling for three volcanic systems in southern Spain. Their study emphasizes the importance of the dimensionless Biot number, describing the balance between conductive and convective heat losses, in controlling thermal evolution (Carrigan 1988).

\section{Concluding remarks}

Our view of crustal magmatic systems has evolved considerably from the 'boiling vat' concept of the last century, wherein large volumes of predominantly liquid magma evolve by cooling and the physical separation of crystals and melt. The predominance of mushy, crystal-rich systems in controlling the physical and chemical evolution of magmas is a theme running through many contemporary studies of crustal magma systems. In this introduction we have shown that insights into the physical and chemical consequences of mushy systems can be readily gleaned from phase diagrams of simple magmas. The papers presented in this volume all touch to some extent on the complexities of this evolving view of magmatic systems; what emerges is more 'mushmatism' than magmatism. We hope that these papers will provide those interested in crustal magmatic systems with some new perspectives on how crystals and melts move and evolve beneath our feet.

We are grateful for the support of Angharad Hills in producing this book, for the efforts of reviewers in improving the content, and to Jessica Pollitt for professional and efficient editorial support. L. C. acknowledges the support of the Swiss National Science Foundation and thanks the students of the second-year (2015) physical volcanology course for inspiring discussions. L. C. would also like to thank Eva Hartung, David Flöss, Guy Simpson and Urs Schaltegger for many thoughts about the long-term evolution of magmatic systems. J. B. acknowledges support from a European Research Council Advanced Grant 'CRITMAG' and a Wolfson Research Merit Award. He is grateful to the Gordon and Betty Moore Foundation for providing sabbatical support at the California Institute of Technology where many of the ideas expressed in this short introduction were refined through discussions with Ed Stolper and Paul Asimow. Simon Powell is thanked for drafting Figure 1. The comments of Bruce Marsh and an anonymous reviewer were very helpful and served to improve the clarity of this introduction.

\section{References}

AnNen, C. 2009. From plutons to magma chambers: thermal constraints on the accumulation of eruptible silicic magma in the upper crust. Earth and Planetary Science Letters, 284, 409-416, http://doi.org/10.1016/j.eps1. 2009.05.006

Annen, C., Blundy, J. D. \& Sparks, R. 2006. The genesis of intermediate and silicic magmas in deep crustal hot zones. Journal of Petrology, 47, 505-539.

Annen, C., Pichavant, M., Bachmann, O. \& Burgisser, A. 2008. Conditions for the growth of a long-lived shallow crustal magma chamber below Mount Pelee volcano (Martinique, Lesser Antilles Arc). Journal of Geophysical Research, 113, B07209, http://doi.org/ 10.1029/2007JB005049

Asimow, P. D. \& GHIORso, M. S. 1998. Algorithmic modifications extending MELTS to calculate subsolidus phase relationships. American Mineralogist, 83, 1127-1131.

Asimow, P. D., Hirschmann, M. M. \& Stolper, E. M. 1997. An analysis of variations in isentropic melt productivity. Philosophical Transactions of the Royal Society of London. Series A, Mathematical and Physical Sciences, 355, 255-281.

Bachmann, O. \& Bergantz, G. W. 2004. On the origin of crystal-poor rhyolites: extracted from batholithic crystal mushes. Journal of Petrology, 45, 1565-1582, http://doi.org/10.1093/petrology/egh019

Bachmann, O. \& Bergantz, G. W. 2006. Gas percolation in upper-crustal silicic crystal mushes as a mechanism for upward heat advection and rejuvenation of near-solidus magma bodies. Journal of Volcanology and Geothermal Research, 149, 85-102, http://doi. org/10.1016/j.jvolgeores.2005.06.002

Bachmann, O. \& Bergantz, G. W. 2008. Deciphering magma chamber dynamics from styles of compositional zoning in large silicic ash flow sheets. Reviews in Mineralogy and Geochemistry, 69, 651-674, http://doi.org/10.2138/rmg.2008.69.17 
BARboni, M. \& Schoene, B. 2014. Short eruption window revealed by absolute crystal growth rates in a granitic magma. Nature Geoscience, 7, 524-528, http://doi. org/10.1038/ngeo2185

Biggs, J., Bastow, I. D., Keir, D. \& Lewi, E. 2011. Pulses of deformation reveal frequently recurring shallow magmatic activity beneath the Main Ethiopian Rift. Geochemistry Geophysics Geosystems, 12, Q0AB10, http://doi.org/10.1029/2011GC003662

Blundy, J. \& Cashman, K. 2001. Ascent-driven crystallisation of dacite magmas at Mount St Helens, 19801986. Contributions to Mineralogy and Petrology, 140, 631-650.

Blundy, J., Cashman, K. \& Humphreys, M. 2006. Magma heating by decompression-driven crystallization beneath andesite volcanoes. Nature, 443, 76-80, http://doi.org/10.1038/nature05100

Bouvet de Maisonneuve, C., Costa, F., Patia, H. \& Huber, C. 2015. Mafic magma replenishment, unrest and eruption in a caldera setting: insights from the 2006 eruption of Rabaul (Papua New Guinea). In: Caricchi, L. \& Blundy, J. D. (eds) Chemical, Physical and Temporal Evolution of Magmatic Systems. Geological Society, London, Special Publications, 422. First published online May 14, 2015, http://doi. org/10.1144/SP422.2

Bowen, N. L. 1915a. Crystallization - differentiation in silicate liquids. American Journal of Science, 39, 175-191.

Bowen, N. L. 1915b. The later stages of the evolution of the igneous rocks. The Journal of Geology, 23, 1-91.

CARICCHI, L. \& Blundy, J. 2015. Experimental petrology of monotonous intermediate magmas. In: CARICCHI, L. \& Blundy, J. D. (eds) Chemical, Physical and Temporal Evolution of Magmatic Systems. Geological Society, London, Special Publications, 422. First published online July 1, 2015, http://doi.org/10.1144/ SP422.9

Caricchi, L., Burlini, L., Ulmer, P., Gerya, T., VasSalli, M. \& Papale, P. 2007. Non-Newtonian rheology of crystal-bearing magmas and implications for magma ascent dynamics. Earth and Planetary Science Letters, 264, 402-419, http://doi.org/10.1016/j.epsl. 2007.09.032

Caricchi, L., Annen, C., Rust, A. \& Blundy, J. 2012. Insights into the mechanisms and timescales of pluton assembly from deformation patterns of mafic enclaves. Journal of Geophysical Research, 117, http://doi.org/ 10.1029/2012JB009325

Caricchi, L., Simpson, G. \& Schaltegger, U. 2014. Zircons reveal magma fluxes in the Earth's crust. Nature, 511, 457-461, http://doi.org/10.1038/nature 13532

Carrigan, C. R. 1988. Biot number and thermos bottle effect: implications for magma-chamber convection. Geology, 16, 771-774.

Cashman, K. \& Blundy, J. 2013. Petrological cannibalism: the chemical and textural consequences of incremental magma body growth. Contributions to Mineralogy and Petrology, 166, 703-729, http://doi. org/10.1007/s00410-013-0895-0

Cashman, K. V. \& Giordano, G. 2014. Calderas and magma reservoirs. Journal of Volcanology and Geothermal Research, 288, 28-45, http://doi.org/10. 1016/j.jvolgeores.2014.09.007
Charlier, B. L. A. \& Wilson, C. J. N. 2010. Chronology and evolution of caldera-forming and post-caldera magma systems at Okataina Volcano, New Zealand from zircon U-Th model-age spectra. Journal of Petrology, 51, 1121-1141, http://doi.org/10.1093/ petrology/egq015

Coleman, D. S., Gray, W. \& Glazner, A. F. 2004. Rethinking the emplacement and evolution of zoned plutons: geochronologic evidence for incremental assembly of the Tuolumne Intrusive Suite, California. Geology, 32, 433, http://doi.org/10.1130/G20220.1

Comeau, M. J., Unsworth, M. J., Ticona, F. \& SunaGUA, M. 2015. Magnetotelluric images of magma distribution beneath Volcan Uturuncu, Bolivia: implications for magma dynamics. Geology, 43, 243-246, http://doi.org/10.1130/G36258.1

Connolly, J. \& Podladchikov, Y. Y. 2015. An analytical solution for solitary porosity waves: dynamic permeability and fluidization of nonlinear viscous and viscoplastic rock. Geofluids, 15, 269-292.

Cooper, K. M. 2015. Timescales of crustal magma reservoir processes: insights from U-series crystal ages. In: Caricchi, L. \& Blundy, J. D. (eds) Chemical, Physical and Temporal Evolution of Magmatic Systems. Geological Society, London, Special Publications, 422. First published online May 14, 2015, http://doi. org/10.1144/SP422.7

Cooper, K. M. \& Kent, A. J. R. 2014. Rapid remobilization of magmatic crystals kept in cold storage. Nature, 506, 480-483, http://doi.org/10.1038/nature12991

Davidson, J. P., Morgan, D. J., Charlier, R.H. \& Hora, J. M. 2007. Microsampling and isotopic analysis of igneous rocks: implications for the study of magmatic systems. Annual Reviews Earth and Planetary Science, 35, 273-311.

de Saint-Blanquat, M., Law, R. D., Bouchez, J. L. \& Morgan, S. S. 2001. Internal structure and emplacement of the Papoose Flat pluton: an integrated structural, petrographic, and magnetic susceptibility study. Geological Society of America Bulletin, 113, 976-995.

DufeK, J. \& BaChmanN, O. 2010. Quantum magmatism: magmatic compositional gaps generated by meltcrystal dynamics. Geology, 38, 687-690, http://doi. org/10.1130/G30831.1

Ellis, B. S., Bachmann, O. \& WolfF, J. A. 2014. Cumulate fragments in silicic ignimbrites: the case of the Snake River Plain. Geology, 42, 431-434, http://doi. org/10.1130/G35399.1

Floess, D. \& Baumgartner, L. P. 2015. Constraining magmatic fluxes through thermal modelling of contact metamorphism. In: CARICCHI, L. \& Blundy, J. D. (eds) Chemical, Physical and Temporal Evolution of Magmatic Systems. Geological Society, London, Special Publications, 422. First published online June 24, 2015, http://doi.org/10.1144/SP422.8

Frey, H. M. \& Lange, R. A. 2010. Phenocryst complexity in andesites and dacites from the Tequila volcanic field, Mexico: resolving the effects of degassing vs. magma mixing. Contributions to Mineralogy and Petrology, 162, 415-445, http://doi.org/10.1007/ s00410-010-0604-1

GHIORso, M. S. \& SACK, R. O. 1995. Chemical mass transfer in magmatic processes. IV. A revised and internally consistent thermodynamic model for the interpolation 
and extrapolation of liquid-solid equilibria in magmatic systems at elevated temperatures and pressures. Contributions to Mineralogy and Petrology, 119, 197-212.

Giordano, D., Russell, J. K. \& Dingwell, D. B. 2008. Viscosity of magmatic liquids: a model. Earth and Planetary Science Letters, 271, 123-134, http://doi. org/10.1016/j.epsl.2008.03.038

Glazner, A. F., Bartley, J. M., Coleman, D. S., Gray, W. \& TAYLOR, R. Z. 2004. Are plutons assembled over millions of years by amalgamation from small magma chambers? GSA Today, 14, 4-11.

Gonnermann, H. M. \& Manga, M. 2007. The fluid mechanics inside a volcano. Annual Review of Fluid Mechanics, 39, 321-356, http://doi.org/10.1146/ annurev.fluid.39.050905.110207

Gualda, G. A. R. \& GHiorso, M. S. 2014. Phaseequilibrium geobarometers for silicic rocks based on rhyolite-MELTS. Part 1: principles, procedures, and evaluation of the method. Contributions to Mineralogy and Petrology, 168, 1033, http://doi.org/10.1007/ s00410-014-1033-3

Gualda, G. A. R., GHiorso, M. S., Lemons, R. V. \& CARLEY, T. L. 2012. Rhyolite-MELTS: a modified calibration of MELTS optimized for silica-rich, fluid-bearing magmatic systems. Journal of Petrology, 53, 875-890, http://doi.org/10.1093/petrology/egr080

Hildreth, W. \& Wilson, C. J. N. 2007. Compositional zoning of the Bishop Tuff. Journal of Petrology, 48, 951-999, http://doi.org/10.1093/petrology/ egm007

Hill, G. J., Caldwell, T. G. et al. 2009. Distribution of melt beneath Mount St Helens and Mount Adams inferred from magnetotelluric data. Nature Geoscience, 2, 785-789, http://doi.org/10.1038/ngeo661

Holtzman, B. K., Kohlstedt, D. L., Zimmerman, M. E., Heidelbach, F., Hiraga, T. \& Hustoft, J. 2003. Melt segregation and strain partitioning: implications for seismic anisotropy and mantle flow. Science, 301, 1227-1230.

Humphreys, M. C. S., Edmonds, M., Plail, M., BarClay, J., Parkes, D. \& Christopher, T. 2012. A new method to quantify the real supply of mafic components to a hybrid andesite. Contributions to Mineralogy and Petrology, 165, 191-215, http://doi.org/10. 1007/s00410-012-0805-X

Jeffery, A. J., Gertisser, R. et aL. 2013. The preeruptive magma plumbing system of the 2007-2008 dome-forming eruption of Kelut volcano, East Java, Indonesia. Contributions to Mineralogy and Petrology, 166, 275-308, http://doi.org/10.1007/s00410-0130875-4

Katz, R. F. 2008. Magma dynamics with the enthalpy method: benchmark solutions and magmatic focusing at mid-ocean ridges. Journal of Petrology, 49, 20992121, http://doi.org/10.1093/petrology/egn058

Kilgour, G., Blundy, J., Cashman, K. \& Mader, H. M. 2013. Small volume andesite magmas and melt-mush interactions at Ruapehu, New Zealand: evidence from melt inclusions. Contributions to Mineralogy and Petrology, 166, 371-392, http://doi.org/10.1007/ s00410-013-0880-7

Longo, A., Papale, P. et AL. 2011. Magma convection and mixing dynamics as a source of ultra-long-period oscillations. Bulletin of Volcanology, 74, 873-880, http://doi.org/10.1007/s00445-011-0570-0

Marsh, B. D. 1981. On the crystallinity, probability of occurrence, and rheology of lava and magma. Contributions to Mineralogy and Petrology, 78, 85-98.

Marsh, B. D. 1989. Magma chambers. Annual Reviews: Earth and Planetary Science, 17, 439-474.

McKenzIE, D. 1984. The generation and compaction of partially molten rock. Journal of Petrology, 25 , $713-765$.

Melekhova, E., Annen, C. \& Blundy, J. 2013. Compositional gaps in igneous rock suites controlled by magma system heat and water content. Nature Geoscience, 6, 1-5, http://doi.org/10.1038/ngeo1781

Michel, J., Baumgartner, L., Putlitz, B., SchaltegGER, U. \& OvTChAROVA, M. 2008. Incremental growth of the Patagonian Torres del Paine laccolith over 90 k.y. Geology, 36, 459, http://doi.org/10.1130/ G24546A.1

Miller, D. S. \& SMith, R. B. 1999. P and S velocity structure of the Yellowstone volcanic field from local earthquake and controlled-source tomography. Journal of Geophysical Research, 104, 15105-15121.

Montagna, C. P., Papale, P. \& Longo, A. 2015. Timescales of mingling in shallow magmatic reservoirs. In: CARICCHI, L. \& Blundy, J. D. (eds) Chemical, Physical and Temporal Evolution of Magmatic Systems. Geological Society, London, Special Publications, 422. First published online May 27, 2015, http://doi.org/10.1144/SP422.6

Mueller, S., Llewellin, E. W. \& Mader, H. M. 2011. The effect of particle shape on suspension viscosity and implications for magmatic flows. Geophysical Research Letters, 38, L13316, http://doi.org/10. 1029/2011GL047167

Muir, D. D., Barfod, D. N., Blundy, J. D., Rust, A. C., SPARKS, R. S. J. \& Clarke, K. M. 2015. The temporal record of magmatism at Cerro Uturuncu, Bolivian Altiplano. In: CARICCHI, L. \& Blundy, J. D. (eds) Chemical, Physical and Temporal Evolution of Magmatic Systems. Geological Society, London, Special Publications, 422. First published online May 21, 2015, http://doi.org/10.1144/SP422.1

Murphy, M. D., Sparks, R. S. J. ET AL. 1998. The role of magma mixing in triggering the current eruption at the Soufriere Hills Volcano, Montserrat, West Indies. Geophysical Research Letters, 25, 3433-3436, http://doi. org/10.1029/98GL00713

NaKagaWa, M., Wada, K., Thordarson, T., WoOd, C. P. \& GAMBLE, J. A. 1999. Petrologic investigations of the 1995 and 1996 eruptions of Ruapehu volcano, New Zealand: formation of discrete and small magma pockets and their intermittent discharge. Bulletin of Volcanology, 61, 15-31.

NaKamura, M. 1995. Continuous mixing of crystal mush and replenished magma in the ongoing Unzen eruption. Geology, 23, 807-810.

NandedKar, R. H., Ulmer, P. \& MÜntener, O. 2014. Fractional crystallization of primitive, hydrous arc magmas: an experimental study at $0.7 \mathrm{GPa}$. Contributions to Mineralogy and Petrology, 167, 1015, http:// doi.org/10.1007/s00410-014-1015-5

Navon, O. \& StolPer, E. 1987. Geochemical consequences of melt percolation - the upper mantle as a 
chromatographic column. The Journal of Geology, 95 , 285-307.

Newman, S. \& Lowenstern, J. B. 2002. VOLATILECALC: a silicate melt $-\mathrm{H}_{2} \mathrm{O}-\mathrm{CO}_{2}$ solution model written in Visual Basic for excel. Computers \& Geosciences, 28, 597-604.

Paterson, S. R., Okaya, D., Memeti, V., Economos, R. \& Miller, R. B., 2011. Magma addition and flux calculations of incrementally constructed magma chambers in continental margin arcs: combined field, geochronologic, and thermal modeling studies. Geosphere, 7, 1439-1468.

Paulatto, M., Annen, C., Henstock, T. J., Kiddle, E., Minshull, T. A., Sparks, R. S. J. \& Voight, B. 2012. Magma chamber properties from integrated seismic tomography and thermal modeling at Montserrat. Geochemistry Geophysics Geosystems, 13, Q01014, http://doi.org/10.1029/2011GC003892

PIWINSKII, A. J. 1975. Experimental studies of granitoid rocks near San Andreas Fault Zone in coast and transverse ranges and Mojave-Desert, California. Tectonophysics, 25, 217-231.

PIWINSKII, A. J. \& WYLlie, P. J. 1968. Experimental studies of igneous rock series - a zoned pluton in Wallowa Batholith Oregon. Journal of Geology, 76, 205-234.

Pla, F. \& Álvarez-Valero, A. M. 2015. Biot number constraints on the thermal regime of acidic magmas in the subvolcanic crust: an integrated approach using numerical modelling and petrology. In: CARICCHI, L. \& Blundy, J. D. (eds) Chemical, Physical and Temporal Evolution of Magmatic Systems. Geological Society, London, Special Publications, 422. First published online July 28, 2015, http://doi.org/10.1144/ SP422.10

Rabinowicz, M. \& Vigneresse, J. L. 2004. Melt segregation under compaction and shear channeling: application to granitic magma segregation in a continental crust. Journal of Geophysical Research - Solid Earth, 109, http://doi.org/10.1029/2002JB002372

REINERS, P. W. 1998. Reactive melt transport in the mantle and geochemical signatures of mantle-derived magmas. Journal of Petrology, 39, 1039-1061.

Reubi, O. \& Blundy, J. 2009. A dearth of intermediate melts at subduction zone volcanoes and the petrogenesis of arc andesites. Nature, 461, 1269-1273, http:// doi.org/10.1038/nature08510

Reubi, O., Sims, K. W. W., Varley, N., Reagan, M. \& EikenberG, J. 2015. Timescales of degassing and conduit dynamics inferred from ${ }^{210} \mathrm{~Pb}-{ }^{226} \mathrm{Ra}$ disequilibria in Volcan de Colima 1998-2010 andesitic magmas. In: CARICCHI, L. \& Blundy, J. D. (eds) Chemical, Physical and Temporal Evolution of Magmatic Systems. Geological Society, London, Special Publications, 422. First published online May 14, 2015, http://doi.org/10.1144/SP422.5

Schoene, B., Schaltegger, U., Brack, P., Latkoczy, C., Stracke, A. \& Gunther, D. 2012. Rates of magma differentiation and emplacement in a ballooning pluton recorded by $\mathrm{U}-\mathrm{Pb}$ TIMS-TEA, Adamello batholith, Italy. Earth and Planetary Science Letters, 355-356, 162-173, http://doi.org/10.1016/j.epsl. 2012.08.019

SchöpA, A. \& ANNEN, C. 2013. The effects of magma flux variations on the formation and lifetime of large silicic magma chambers. Journal of Geophysical Research Solid Earth, 118, 926-942, http://doi.org/10.1002/ jgrb.50127

Solano, J. M. S., Jackson, M. D., Sparks, R. S. J., Blundy, J. D. \& ANNEN, C. 2012. Melt segregation in deep crustal hot zones: a mechanism for chemical differentiation, crustal assimilation and the formation of evolved magmas. Journal of Petrology, 53, 19992026, http://doi.org/10.1093/petrology/egs041

Solano, J. M. S., Jackson, M. D., Sparks, R. S. J. \& BLUNDY, J. 2014. Evolution of major and trace element composition during melt migration through crystalline mush: implications for chemical differentiation in the crust. American Journal of Science, 314, 895-939, http://doi.org/10.2475/05.2014.01

Stevenson, D. J. 1989. Spontaneous small-scale melt segregation in partial melts undergoing deformation. Geophysical Research Letters, 16, 1067-1070.

Stolper, E. \& Asimow, P. 2007. Insights into mantle melting from graphical analysis of one-component systems. American Journal of Science, 307, 1051-1139.

Storm, S., Shane, P., Schmitt, A. K. \& Lindsay, J. M. 2011. Decoupled crystallization and eruption histories of the rhyolite magmatic system at Tarawera volcano revealed by zircon ages and growth rates. Contributions to Mineralogy and Petrology, 163, 505-519, http://doi.org/10.1007/s00410-011-0682-8

Storm, S., Schmitt, A. K., Shane, P. \& Lindsay, J. M. 2014. Zircon trace element chemistry at submicrometer resolution for Tarawera volcano, New Zealand, and implications for rhyolite magma evolution. Contributions to Mineralogy and Petrology, 167, 1000, http://doi.org/10.1007/s00410-014-1000-z

Thomson, A. \& Maclennan, J. 2012. The distribution of olivine compositions in Icelandic basalts and picrites. Journal of Petrology, 54, 745-768, http://doi.org/ $10.1093 /$ petrology/egs083

Ward, K. M., Zandt, G., Beck, S. L., Christensen, D. H. \& McFarlin, H. 2014. Seismic imaging of the magmatic underpinnings beneath the AltiplanoPuna volcanic complex from the joint inversion of surface wave dispersion and receiver functions. Earth and Planetary Science Letters, 404, 43-53, http://doi.org/ 10.1016/j.eps1.2014.07.022

Whitney, J. A. \& Stormer, J. C. 1985. Mineralogy, petrology, and magmatic conditions from the fish canyon tuff, central San Juan volcanic field, Colorado. Journal of Petrology, 26, 726-762, http://doi.org/ $10.1093 /$ petrology/26.3.726

Wilson, C. J. N. \& Charlier, B. L. A. 2009. Rapid rates of magma generation at contemporaneous magma systems, Taupo Volcano, New Zealand: insights from U-Th model-age spectra in zircons. Journal of Petrology, 50, 875-907, http://doi.org/10.1093/petrology/ egp023

Wotzlaw, J.-F., Schaltegger, U., Frick, D. A., DunGAN, M. A., Gerdes, A. \& GÜNTHER, D. 2013. Tracking the evolution of large-volume silicic magma reservoirs from assembly to supereruption. Geology, 41, 867-870, http://doi.org/10.1130/G34366.1

Wotzlaw, J. F., Bindeman, I. N., Watts, K. E., Schmitt, A. K., Caricchi, L. \& Schaltegger, U. 2014. Linking rapid magma reservoir assembly and eruption trigger mechanisms at evolved Yellowstone-type 
supervolcanoes. Geology, 42, 807-810, http://doi. org/10.1130/G35979.1

ZANON, V. 2015. Conditions for mafic magma storage beneath fissure zones at oceanic islands. The case of São Miguel Island (Azores archipelago). In: CARICCHI, L. \& Blundy, J. D. (eds) Chemical, Physical and Temporal Evolution of Magmatic Systems. Geological Society, London, Special Publications, 422. First published online May 27, 2015, http://doi.org/10.1144/ SP422.4
Zellmer, G. F., Rubin, K. H., Miller, C. A., Shellnut, J. G., Belousov, A. \& Belousova, M. 2015. Resolving discordant $\mathrm{U}-\mathrm{Th}-\mathrm{Ra}$ ages: constraints on petrogenetic processes of recent effusive eruptions at Tatun Volcano Group, northern Taiwan. In: CARICCHI, L. \& Blundy, J. D. (eds) Chemical, Physical and Temporal Evolution of Magmatic Systems. Geological Society, London, Special Publications, 422. First published online May 14, 2015, http://doi.org/10.1144/ SP422.3 